\title{
THE EXPERIENCE OF THE AFRICAN UNION IN THE PROCESS OF RESOLVING REGIONAL CRISES
}

\section{Afrika Birliği'nin Bölgesel Krizlerin Çözümü Sürecinde Deneyimi}

\author{
Alexandr CAUIA* \\ Naif Jassim ALABDULJABBAR**
}

\section{ABSTRACT}

The African continent has proven to be the area most severely affected by the armed conflicts and military mutinies that have caused and continue to substantially affect the peace and security process on the continent and beyond.

This article reflects the process of building, the importance and structure of the African Union, the Peace and Security Council and the African Peace and Security Architecture as mechanisms and tools for preventing and combating violations of peace and security. The legal and regulatory framework for prevention and intervention in armed conflicts, military mutiny and attempts to unconstitutional seizure of power, both inside and outside Member States, are also analyzed.

Keywords: Regional peace and security, African Union, Peace and Security Council, African Peace and Security Architecture.

Africa has a long conflict history, either civil wars, qualified as noninternational armed conflicts, or international armed conflicts. In the last 50 years, armed conflicts have taken place in about 30 countries or in $65 \%$ of the states on this continent. The periods of these conflicts were different, two thirds of which lasted no more than 5 years, while 22 percent of the total ended after 11 or more years of war. ${ }^{1}$

Makale Geliş Tarihi: 29.03.2021, Makale Kabul Tarihi: 03.06.2021.

$\mathrm{PhD}$ in Law, Associate Professor, Free International University of Moldova (ULIM), (acauia@ulim.md, ORCID: 0000-0002-1952-5734)

** $\mathrm{PhD}$ student, Free International University of Moldova (ULIM), (naifjassem@ hotmail.com, ORCID: 0000-0002-2220-0359)

1 Vines A. A decade of African Peace and Security Architecture. International Affairs. Nr. 89 (1), 2013, p. 93-94. 
Recent trends and developments clearly reflect this dynamic on the African continent. Today, almost $75 \%$ of all assigned personnel in peace operations are deployed in Africa, which also hosts the vast majority of peacekeeping operations. ${ }^{2}$ In addition, new operational and regulatory developments in peacekeeping operations, such as increasingly robust and incisive mandates and the use of modern technologies, tend to materialize in Africa.

The longest-running armed conflicts took place in Sudan, which began in 1983 and was resolved only in early $2005,{ }^{3}$ Angola, Somalia and the conflict in Ethiopia. ${ }^{4}$ From 1955 to 2009, it is estimated that about $40 \%$ of the world's armed conflicts took place in Africa, including inter-ethnic conflicts and civil wars. In 2000, 67\% of all non-international armed conflicts in the world took place on this continent.

In the second decade of the twentieth century, Africa continued to be affected by armed conflict, for example in 2011 there were three armed conflicts, and in 2012 there were 4 wars, including two coups provoked by the military. ${ }^{5}$ The vast majority of these conflicts are non-international. Some of these crises have spread to neighboring countries. For example, the conflict in Rwanda has affected other conflicts in Burundi, the Democratic Republic of the Congo, Tanzania and Uganda. ${ }^{6}$

The African Union (AU) is a continental organization mandated to work to prevent and address peacekeeping and security issues. Although national interests seem to prevail over common values and continental benefits, it would seem that the AU is more than the sum of all Member States. This organization has its own institutions, budget, policies and agreements, indicating a certain degree of independence and despite being founded by the leaders of African States, it has followed its own path of development. On the one hand, the AU cannot dictate changes in the peace

2 Van der Lijn J., Smit T. et Höghammar T., Peace operations and conflict management, SIPRI, Yearbook 2016: Armaments, Disarmament and International Security. Oxford University Press: Oxford, 2016, p. 269-319.

3 Makinda S.M., Okumu F. W. The African Union, challenges of globalisation, security and governance. New York: Routledge Global Institutions, 2008, p. 75.

4. Buzan B., Wever, O. Regions and Powers, the structure of international security. Cambridge: Cambridge University Press, 2003, p. 245.

5 Vines A. A decade of African Peace and Security Architecture. International Affairs. Nr. 89 (1), 2013, p. 93.

6 Makinda S.M., Okumu F. W. The African Union, challenges of globalisation, security and governance. New York: Routledge Global Institutions, 2008, p. 75. 
and security policies of African States, on the other hand, its role can no longer be ignored in the continent's peace programs.

The Constitutive Act of the African Union considers peace and stability as pillars of the continental project. Article 3 describes, inter alia, the objective:" to promote peace, security and stability on the continent". ${ }^{7}$

The African Union emerged during the period when the African space was devoured by the conflict, and their prevention and resolution was the basic function of the organization. The major hopes were that the African Union would do better in this mission than the OAU. In situations where peaceful intervention failed, the AU resorted to military intervention. ${ }^{8}$

The new structure has the right to intervene in the internal affairs of a Member State, including the use of military force, if necessary, to protect the population from flagrant violations of human rights. For the AU, sovereignty is conditional and is based on the state's ability and availability to protect its citizens. $^{9}$

The history of the African Union would not be described in all its aspects if we did not begin this analysis with the Organisation of African Unity (OAU). Thus, the OAU was stablished on May 25, 1963 in Addis Ababa, when representatives of 32 African states signed a Charter to form the organization. Over time, other 21 African countries later joined, and the number of members of the Organization increased to $53 .{ }^{10}$

The AU was officially established in 2002 on the principles adopted by the OAU, namely; sovereignty, equality and interdependence, as well as

7 African Union Constitutive Act of the African Union. 11.07.2000, Lome, Togo. [online] https://au.int/sites/default/files/pages/34873-file-constitutiveact_en.pdf (accessed 28.12.2020)

8 Agu, S. U., Okeke, V. O. The African Union (AU) and the challenges of conflict resolution in Africa. British Journal of Arts and Social Sciences, 2013. Nr. 14(11), p. 280 288.

9 Powell K. The African Union's emerging peace and security regime opportunities and challenges for delivering on the responsibility to protect (ISS Monograph Series No. 119). Pretoria: Institute for Security Studies, 2005. [On line] https://www.africaportal.org/publications/the-african-unions-emerging-peace-and-securityregime-opportunities-and-challenges-for-delivering-on-the-responsibility-to-protect/ (accessed 15.12.2019)

10 Joshua S. J., Olanrewaju F. The AU's Progress and Achievements in the Realm of Peace and Security. India Quarterly 73(4), Indian Council of World Affairs ICWA, SAGE Publications, 2017. p 4. 
respect for existing borders. ${ }^{11}$ This principle is linked to the traditional definition of security, in which security refers to the issue of territory, state borders and national security. ${ }^{12}$

This definition seems to be limited to the notion of military security, but after the Cold War ended the OAU began to use a broader explanation of security, including non-military aspects. ${ }^{13}$

As a result of the colonial system that generated a number of negative consequences for the entire African continent, the OAU had responsibility of freeing the continent from European colonialism, racism and apartheid, and decolonization became one of the priority tasks of the OAU. Aside from its role of liberation of African countries that were then under the grip of colonialism, the OAU was also confronted with numerous interstate and intrastate conflicts, which afflicted many countries in the continent shortly after their independence, from Great Lakes to the Horn of Africa, and virtually the entire continent.

Many of these conflicts originated from struggles for political power, religious supremacy and ethnic domination, others occurred from the impossibility of popular participation in governance and the truncation of the democratic process by military intervention in political affairs. ${ }^{14}$

The OAU recorded a big success in its primary mission of liberating the continent from colonialism with the help of international actors when, on 27 April 1994, a new government under the leadership of Nelson Mandela, became a reality in South Africa. Contrary to expectations, the OAU failed in the aspect of monitoring and controlling the actual situation in its own member states. This became obvious as a result of its inability to curb violent conflicts, poor governance, poor economic management, gender inequality, human rights violation and poverty in the region. ${ }^{15}$

11 Makinda S.M., Okumu F. W. The African Union, challenges of globalisation, security and governance. New York: Routledge Global Institutions, 2008, p. 37.

12 Soderbaum F., Tavares R. Problematizing regional organisation in African security. African Security. 2 (2-3), 2009, p. 76.

13 Soderbaum F., Tavares R. Problematizing regional organisation in African security. African Security. 2 (2-3), 2009, p. 76.

14 Shinkaiye K. Nigeria and the African Union: Roles and expectation. In B. Akinterinwa (Ed.), Nigeria and the development of the African Union. Ibadan: Vantage Publishers, 2005, p. 76-97

15 Murithi T. Proactive interventionism: The African Union, Peace and Security Councils engagement in the Horn of Africa. Journal of Conflict Resolution, Nr. 12, 2012, p. 87-111. 
Even though in 1993 in Cairo the OAU established a Mechanism for Conflict Prevention, Management and Resolution, this instrument was ineffective due to its failure to resolve disputes in the continent. It is tragic to discover that the Rwandan genocide which started in April 1994 happened shortly after this mechanism became operational. In the same vein, the situation in the conflict that led to the collapse of Somalia and the violent conflicts that led to the deaths of millions of Africans in Angola, the Democratic Republic of Congo, Liberia and Sierra Leone took place. These catastrophic events have developed the weakness of the OAU as a tool or mechanism for prevention and conflict resolution. ${ }^{16}$

Poor governance, violence and insecurity pose a high risk of creating regional challenges, affecting political and economic stability. The scourge of conflicts in Africa is the major impediment to the social and economic development. This makes the peace and security policy of the AU a prerequisite for implementing the development and integration agenda. ${ }^{17}$

This well-defined purpose is legally grounded. Political tools and mechanisms, monitoring missions and military interventions are all available to the AU. This structure was the first international actor to adopt the concept of Responsibility to Protect (R2P). ${ }^{18}$ For African scientists and political leaders, this decision indicated a shift from a sphere of nonintervention to non-indifference. Article 4 (h) was amended in 2003 to add other rights to intervene in the event of "serious threats". However, this amendment to the Constitutive Act of the African Union is not ratified by all members. ${ }^{19}$ Member States had reservations about these provisions and feared a possible interference by the Peace and Security Council (PSC) in domestic policy. A permanent break with the non-intervention tradition of the Organisation of African Unity (OAU) has not yet been achieved.

16 Murithi T. The African Union's evolving role in peace operations: The African Union Mission in Burundi, the African Union Mission in Sudan and the African Union Mission in Somalia. African Security Review, 17(1), Taylor \& Francis, 2008. p. 70-82.

17 African Union Constitutive Act of the African Union. 11.07.2000, Lome, Togo. [online] https://au.int/sites/default/files/pages/34873-file-constitutiveact_en.pdf (accessed 28.12.2020)

18 Freire M. R., Lopes P. D. Nascimento, D., Responsibility to Protect and the African Union: Assessing the AU's Capacity to Respond to Regional Complex Humanitarian and Political Emergencies, African Security Review, 2016, Nr. 25 (3) p. 223-241

19 Peen R. A., The African Union Mission in Burundi, Civil Wars, 2012, Nr. 14 (3), 376. p. 373-392. 
One of the main findings was that, despite the overwhelming consensus on the concepts and principles applied to peace operations, as well as the critical importance given to peace operations in global conflicts resolution, the number and scope of operations are likely to stagnate in some regions, considered as confluences of the interests of the great powers. However, Africa, and especially sub-Saharan Africa, will be a clear exception. ${ }^{20}$

In order to implement its principles and objectives, the AU has a special structure called the Peace and Security Council (PSC) officially founded in 2004. Relations between the members of the PSC are based on equality and there is no permanent member with a veto power. ${ }^{21}$ The PSC has the task of promoting peace and security among the Member States of the Union, as expressly set out in Article 3 (f) of the AU Charter. In the same vein, under Article 5 (2), a common defense and security policy has been created for the mainland states to support the PSC..$^{22}$ The Peace and Security Council has the following basic functions:

a) to anticipate and prevent conflicts,

b) to manage ongoing tensions and promote peace and security.

To implement these aims, the AU has a structure and mechanism called the African Peace and Security Architecture (APSA). ${ }^{23}$ It is the platform for cooperation between the PSC and a number of AU bodies, including the political and economic council, such as:

a) African Standby Force (ASF) - this instrument is designed to supply troops whenever military ground action is needed,

b) the continental early warning system (CEWS) - monitors and observes, as well as analyzes the political, economic, social and security situation, collects the necessary data for the PSC. Therefore, this early warning information can be used to prevent conflicts.

20 Van der Lijn J., Avezov, X., The Future Peace Operations Landscape: Voices from Stakeholders Around the Globe, Final Report of the New Geopolitics of Peace Operations Initiative, SIPRI: Stockholm, 2015. 90 p.

21 Williams P.D. War and conflict in Africa. Cambridge: Polity Press, 2011, p. 158.

22 Makinda S.M., Okumu F. W. The African Union, challenges of globalisation, security and governance. New York: Routledge Global Institutions, 2008, p. 87.

23 Vines A. A decade of African Peace and Security Architecture. International Affairs. Nr. 89 (1), 2013, p. 97 . p. 
c) Panel of the Wise - is a council of five honorable people who give several recommendations and opinions on the conflict situation.

d) African Peace Facility (APF); it is a council that provides funds for the peace mission. ${ }^{24}$

The AU is not the only regional security organization. There are several similar institutions that have been set up in other regions, such as NATO in Europe, the Arab League of (AL) and the Central Treaty Organization (CENTO) in the Middle East, the Organization of American States (OAS) and the Caribbean Community (CARICOM) in America, the Southeast Asia Treaty Organization (SEATO) and the Association of Southeast Asian Nations (ASEAN) in Asia, in Australasia there is the Commonwealth and the Australia, New Zealand, United States Security Treaty (ANZUS) ${ }^{25}$

The construction of such international organizations confirms the urgent need for security in each region. The objectives of creating such an organization are to prevent social, political and economic conflicts in certain areas, because the security of a state is influenced by both the external security environment and the level of internal security. ${ }^{26}$

This position is inspired by the definitions of regional security given by B. Buzan who says that regional security is the state of affairs in which a group of states have a common concern about the security problems of the region, because they realize that the security of a nation cannot be separated from other nations. In the African context, there are several examples of an intra-state conflict that later spread to one of the neighboring countries, such as Somalia and Sudan, Ethiopia and Sudan, Sudan and Uganda, Uganda and Rwanda, Rwanda and Zaire / Democratic Republic of the Congo (DRC), Zaire / DRC and Angola. ${ }^{27}$

Building the African Union is a response to several challenges related to security issues and to finding a resolution to these issues. There are several factors that have influenced the formation of the AU, such as the end of the

24 Makinda S.M., Okumu F. W. The African Union, challenges of globalisation, security and governance. New York: Routledge Global Institutions, 2008, p. 87.

25 Fawcett L. Regional Security. Security Studies an Introduction. London: Routledge, 2013, p. 356.

26 Fawcett L. Regional Security. Security Studies an Introduction. London: Routledge, 2013, p. 356.

27 Buzan B., Wever, O. Regions and Powers, the structure of international security. Cambridge: Cambridge University Press, 2003, p. 232. 
Cold War, the need to ensure the application of human rights, a certain tension among states on the African continent to identify the leader among them. In addition, the AU is the regional structure that is to continue the activities of the Organisation of African Unity, a structure that aimed to protect the sovereignty and security, as well as the integrity of the Member States, in order to build a network of solidarity between members. ${ }^{28}$

Under the auspices of the AUO, several peacekeeping missions were carried out. For example, in 1991 there was a peacekeeping operation in Western Sahara-Morocco, in 1991-1993 there was a team of military observers and a monitoring group sent to Rwanda, in 1993-1996 an observer mission in Burundi, in 1999-2000 an observer mission in the Republic of Congo and 2001-2002 a military mission in the Comoros, as well as from 2000 to 2008 a liaison mission in Ethiopia-Eritrea. ${ }^{29}$

In order to achieve its goal of maintaining peace and security in Africa, the AU established a set of conflict management mechanisms and tools. Basic instruments for conflict management include: peaceful negotiations, mediation initiatives, consensual peacekeeping interventions, peacekeeping operations, minimizing the occurrence of conflicts through peacekeeping actions and a system of sanctions. ${ }^{30}$

Unlike the OAU, which supported the principle of non-interference in the internal affairs of its members, the PSC, since its first meeting in 2004, has conducted $\mathrm{AU}$ missions in conflict areas, for example, Comoros, Burundi (2003-2004), Sudan, Darfur (2004-2007), Democratic Republic of the Congo, Ivory Coast and Somalia, etc. The AU sent observers to monitor the elections in several African countries, such as Sudan and Somalia. PSC has resolved post-election violence in Kenya and Ivory Coast.

It is remarkable how, especially in the early years of the AU, African states and state leaders were praised for their efforts. PSC "expresses its appreciation to His Excellency Professor Faustin Archange Touadera, for his leadership and vision, as well as for the leaders of the armed groups for

28 Makinda S.M., Okumu F. W. The African Union, challenges of globalisation, security and governance. New York: Routledge Global Institutions, 2008, p. 23.

29 Williams P.nD. War and conflict in Africa. Cambridge: Polity Press, 2011, p. 151.

30 Williams P. D. The African Union's conflict management capabilities (Working Paper). International Institution and Global Governance Program, New York. 2011. p. 129 [On line] https://www.files.ethz.ch/isn/146220/IIGG_WorkingPaper7.pdf (accessed 21.12.2019) 
patriotism and commitment." ${ }^{31}$ After the forced abdication of Mugabe, which caused instability in Zimbabwe, the president of the Council said he would be "remembered as a fearless pan-Africanist liberation fighter" and his withdrawal "was a state act". ${ }^{32}$ This illustrates how the legacy of African leaders, their position in the network, cannot be denied by the AU. It is noteworthy that the older decisions of the PSC mentioned African leaders nominally. ${ }^{33}$ Thus, the success of the AU was determined by the availability of states and the support of African leaders in its early years more than today.

A complex security mechanism specific to the African continent is APSA. ${ }^{34}$ It was created in the early 2000 s to help peace and security structures better protect civilians and respond to human rights violations and abuses in times of armed conflict. ${ }^{35}$ Since then, however, the security environment has changed considerably in many parts of Africa, which has implications for the future development of the APSA, including the postponed African Standby Force (ASF) and African-led peacekeeping operations. ${ }^{36}$ In particular, experts and practitioners stressed that APSA

31 African Union Peace and Security Council, Communiqué. Peace and Security Council 826th meeting Addis Ababa, Ethiopia, 9 February 2019. [online] http://www.peaceau.org/uploads/psc.826.meeting.comm.car.9.02.2019.pdf (accessed 15.10.2019).

32 African Union Peace and Security Council, Statement of the Chairperson of the Commission of the African Union on the Situation in Zimbabwe. 2017. [online] http://www.peaceau.org/uploads/auc-statement-zimbabwe-21 nov2017english.pdf (accessed 21.10.2019).

33 African Union Peace and Security Council, Communiqué. Peace and Security Council 87th meeting, 13 August 2007, Addis Ababa, Ethiopia. 2008. [online] http://www.peaceau.org/uploads/communiqueeng.pdf (accessed 21.12.2019).

34 Badmus I. A., The African Union's Role in Peacekeeping: Building on Lessons Learned from Security Operations, Palgrave Macmillan: Basingstoke, 2015, 277 p.; Lotze, W., Strengthening African peace support operations: nine lessons for the future of the African Standby Force, Center for International Peace Operations (ZIF) Policy Briefing, déc. 2013. 4 p.; Williams, P. D., Boutellis, A., Partnership peacekeeping: challenges and opportunities in the United Nations- African Union relationship, African Affairs, vol. 113, no. 451 (2014), p. $254-278$.

35 Engel U., Porto G. D., Towards an African Peace and Security Regime: Continental Embeddedness, Transnational Linkages, Strategic Relevance. Burlington:Ashgate, 2013. $276 \mathrm{p}$.

36 Aning K., Abdallah M., Confronting hybrid threats in Africa: improving multidimensional responses. In: De Coning C., Gelot L. Karlsrud J. The Future of African Peace Operations: From the Janjaweed to Boko Haram London: Zed Books, 2016, p. 20-38; Dersso S. A., Confronting hybrid threats in Africa: improving multidimensional responses, ed. de Coning, Gelot and Karlsrud. The Future of African Peace Operations: From the 
needs to be improved and that it has the means to address the challenges associated with terrorism, disaster management, piracy and post-conflict reconstruction, as well as transnational organized crime, climate change and food insecurity. ${ }^{37}$

The Union has established a legal and institutional peace and security architecture to monitor and respond to threats, including the mandate to deploy troops on the territory of sovereign states. ${ }^{38}$ The existence of the Peace and Security Architecture in Africa and the normative and legal framework offers the possibility for the AU to become an independent actor from the African member states, emancipated and discovered new ways to influence the attitudes of the states and to achieve African solidarity. ${ }^{39}$ Williams P.D. calls PSC an international embryo institution: "even in its suboptimal state it has had a significant impact on the security dynamics in Africa." 40 This evolution of the AU as a peace actor illustrates its conception and essence - to behave as a powerful generator of peace, becoming an important actor in a region affected by conflicts and eruptions of violence.

Particular attention was paid to the African Union (AU) and subregional African entities, indicating the key role they should continue to play in organizing future peace operations on the continent. ${ }^{41}$ However, despite improved African skills and capabilities for peace operations and strong

Janjaweed to Boko Haram London: Zed Books, 2016, p. 38-52; Leijenaar A., Africa can solve its own problems with proper planning and full implementation of the African Standby Force, Blog post, Institute for Security Studies, 21.01.2004, [online] https://www.issafrica.org/iss-today/africa-can-solve-its-ownproblems-with-properplanning-and-full-implementation-of-the-african-standby-force>.(accessed 25.09.2019).

37 Aning K., Abdallah M., Confronting hybrid threats in Africa: improving multidimensional responses. In: De Coning C., Gelot L., Karlsrud J. The Future of African Peace Operations: From the Janjaweed to Boko Haram London: Zed Books, 2016, p. 20-38.

38 African Union Constitutive Act of the African Union. 11.07.2000, Lome, Togo. Art. 4 (j) and 9(g) [online] https://au.int/sites/default/files/pages/34873-file-constitutiveact_en.pdf (accessed 28.12.2020)

39 Barnett M., Coleman L. Designing Police: Interpol and the Study of Change in International Organisations, International Studies Quarterly, 2005, Nr. 49 (4), p. 598. p. 593-619. [On line]https://home.gwu.edu/ barnett/articles/2005_designing_isq.pdf (accessed 15.10.2020)

40 Williams P.D., The Peace and Security Council of the African Union: Evaluating an Embryonic International Institution', Journal of Modern African Studies 47 (4), 2009, p. 604; Williams, P. D., The "Responsibility to Protect", Norm Locatisation, and African International Society, Global Responsibility to Protect, 2009, Nr. 1 (3), p. 392-416.

41 UN, General Assembly, Report of the High-level Independent Panel on Peace Operations on uniting our strengths for peace: politics, partnership and people (A/70/95-S/2015/446). 
demands for greater African intervention capability, the African Peace and Security Architecture (APSA) will not reach its full operational capability as long as the continent will not be able to assume all the military, development and civil imperatives of multidimensional peace operations, at least not in the short and medium term. It is therefore relevant and appropriate to consider how to improve international cooperation in African peace operations.

Even if the African Union has its own peace and security mechanism for Africa (APSA), but during peacekeeping operations, this body cannot be separated from the intervention of other competent international organizations in this field.

Thus, the African Union contributes significantly to the conflict resolution process in several areas of Africa. From 2003 to 2008, the AU sent about 15,000 troops to the fighting zone in Burundi, Sudan, the Comoros and Somalia. ${ }^{42}$

Some of these contingents have actively cooperated with international actors responsible for peacekeeping. For example, the first peacekeeping mission initiated before the creation of the PSC, conducted by the AU, was in Burundi (AMIB) from 2003 to 2004. This mission consisted of deploying troops from South Africa, Ethiopia and Mozambique for a two-year term and was then taken over by the UN. After that, this African operation was under UN command and was funded by the UN. ${ }^{43}$ This mission was later called UN Operation in Burundi (ONUB), and later in 2007 the AU sent a military contingent to Burundi to help achieve the Dar-es-Salaam peace agreement between the government and the opposition. ${ }^{44}$

The next mission was to Darfur in Sudan (AMIS). In this operation, the AU sent 100 observers to Darfur in 2004. Then, in 2005, the AU sent 7,000 troops to this country. ${ }^{45}$ This operation was almost entirely sponsored by

42 Soderbaum F., Tavares R. Problematizing regional organisation in African security. African Security. 2009, Nr. 2 (2-3), p. 78.

43 Sturman K., Hayatou A. The Peace and Security Council of the African Union: from design to reality. In: Africa's New Peace and Security Architecture; Promoting Norms, Institutionalizing Solutions. UK: Ashgate, 2010, p. 70-71.

44 Soderbaum F., Hettne B. Regional security in a global perspective. In: Africa's New Peace and Security Architecture; Promoting Norms, Institutionalizing Solutions. UK: Ashgate, 2010, p. 22.

45 Makinda S.M., Okumu F. W. The African Union, challenges of globalisation, security and governance. New York: Routledge Global Institutions, 2008, p. 118. 
external donations, such as from 2003 to 2007 the European Union (EU) donated 250 million euros for this mission. Subsequently, AMIS became the UN-AU mission in Darfur (UNAMID), and in 2008 the EU granted another 300 million Euro for the mission. ${ }^{46}$

The Republic of Togo was suspended from membership between February and May 2005 and the Comoros, when Mohamed Taki Abdoulkarim died in office and his son fraudulently retained power by manipulating the elections of that time and won other elections in 2010. In Madagascar, Guinea and Niger, some members of the military junta were not allowed to participate in the elections. There are cases in which the presidents of African states such as Uganda and Algeria have eliminated the norms related to the procedures for electing the president and maintained power by manipulating the election results. In this case, the AU did not have the capacity to impose sanctions against such violations. ${ }^{47}$

The AU approach to peace-making in the post-Cold War era reflects its member states' preference for consensual decision-making between the belligerent parties and the Peace and Security Council. A good example is the power-sharing agreement and deployment of 462 troops to support elections in the Comoros in May 2006. ${ }^{48}$ The drastic decline in coups and conflicts, as well as the increase in the number of elections held in Africa in recent decades, show that the AU has managed to balance the actions of states and give them new performance and political values. ${ }^{49}$

Other cases where AU had monitored power-sharing arrangements include Sudan, Ivory Coast, Chad and Zimbabwe (2008-2009), Libya and Liberia (1994-2003), Côte d'Ivoire (2002-2007) and Central African Republic (1996-2007). ${ }^{50}$

46 Ulf E., Gomes Porto J. Africa's New Peace and Security Architecture: Promoting Norms, Institutionalizing Solutions. In: Africa's New Peace and Security Architecture; Promoting Norms, Institutionalizing Solutions. UK: Ashgate, 2010, p. 4

47 Omorogbe E. Y. A club of incumbents? The African Union and coups d'etat. Vanderbilt Journal of Transnational Law, 2008. Nr. 44(1), p. 127[On line] https://www.dphu.org/uploads/attachements/books/books_3824_0.pdf (accessed 15.10.2020)

48 Oguonu C. N., Ezeibe, C. C. African Union and conflict resolution in Africa. Mediterranean Journal of Social Sciences, 2014. Nr. 5(27), p. 325-332.

49 Lisk F. The African Union after 10 Years: Successes and challenges. (2012) [online] http://www2.warwick.ac.uk/newsandevents/expertcomment/the_african_union/(ac cessed 05.01.2021)

50 Mehler A. Not always in the people's interest: Power-sharing arrangements in African peace agreements. Hamburg: GIGA Working Papers, 2008. Nr. 83, p. 6. 
Sovereignty, even if it has lost its "presumption of innocence", is still distinguished by its resistance. This formula of Jürgen Habermas taken over by Professor Dodzi Kororoko shows that in the face of state sovereignty, this sacrosanct principle, which is constantly opposed to foreign interventions and is further strengthened by the rules of intangibility of borders inherited from colonization, prevails a right to peace and security, which, in the end, must be imposed. ${ }^{51}$

The peace-building process in Africa is no exception to this finding. The African Peace and Security Architecture of AU was inspired by the logic of peacekeeping adopted within the UN's centralized collective security system. Under this security system, nothing, not even the principle of noninterference in matters falling within the national jurisdiction of States, prevents the Security Council from using the enforcement measures provided for in Chapter VII of the Charter of the United Nations. ${ }^{52}$

This implies that the rule of conflicts resolution should not be absolute in a context where the parties to the conflict dissociate themselves from the peace resolutions adopted. Therefore, the AU has not failed to offer, beyond the right to humanitarian intervention inspired from a doctrinal point of view, a real right of intervention ${ }^{53}$ that can be implemented when the parties to the conflict explicitly or tacitly express their unwillingness to contribute to the non-violent peacekeeping process initiated by African Peace and Security Architecture.

The expansion of the role of the AU and the influence it wants to have on local communities is in contrast to the image of a global continental body. PSC declarations and decisions address African societies as sources of conflict and are partners in providing resolutions. The AU is working to build a "people-centered Union" 54 that involves the principle of subsidiarity.

51 Kokoroko D., Avons-nous encore besoin du droit international de la démocratie? In: Mélanges François HERVOUET, Entre les ordres juridiques, LGDJ, 2015, p.620-627.

52 United Nations Charter. 24.10.1945, Article 2 (7). [online] https://www.un.org/en/sections/un-charter/un-charter-full-text/ (accessed 23.12.2020)

53 Fopy S. Ch., Le droit d'intervention de l'Union Africaine, Mémoire de DEA en Droit Communautaire et comparé CEMAC, Université de Dschang, 2006, 128 p.

54 African Union High Level Retreat, On the Promotion of Peace, Security and Stability "Strengthening African Union's Conflict Prevention and Peacemaking Effort." 2018. [online] http://www.peaceau.org/uploads/2018-1026-au-hlr-9-declarationlatest.pdf (accessed 25.11.2020). 
The distinct position and principles of complementarity and subsidiarity of the PSC are often mentioned in the recent work of this institution. ${ }^{55}$ States call on the Council to have a coordinating role for regional organizations. These regional economic communities and regional mechanisms are familiar to states and have had experience in the peacekeeping process in recent years. The PSC considers them partners in the Pan-African ideal and takes advantage of their local position to implement the AU peace policy.

The AU, as a Union of African states in peace activities, cannot deny smaller peace actors, which are less complex and enjoy the confidence of states. Regional organizations are forward-looking tools or agenda-setting tools.

The development of relations between the AU and the Africa's Regional Economic Communities (RECs) / Regional Mechanisms (RMs) and in accordance with the principle of subsidiarity, important issues should be addressed at the nearest level, including local level, compatible with their approach, which is a key issue affecting the very future of peace operations in Africa. ${ }^{56}$

For example, Ndiaye M. argues that while the principle of subsidiarity is fundamental to the relationship between the $\mathrm{UN}$, the $\mathrm{AU}$ and the RECs/RMs, it has often become an obstacle when it comes to providing strategic and rapid responses to specific crises. Disputes over the essence of this principle and disagreements on how it should be interpreted tend to slow down action when rapid response is required.$^{57}$ Gebrehiwot B.M. and A. de Waal stress the importance of clarifying the role of the subsidiarity principle and the need to establish a stronger agreement between the AU and the $\mathrm{RECs} / \mathrm{RMs}$, in order to define the cooperative relationship between these entities..$^{58}$

55 African Union High Level Retreat, Third African Union High-Level Retreat of Special Envoys and Representatives on the Promotion of peace, Security and Stability in Africa. Cairo Declaration. 2012. [online] http://www.peaceau.org/uploads/auc.declaration.cairo.pdf (accessed 23.12.2020).

56 Fisher L. M. et al., African Peace and Security Architecture (APSA): 2010 assessment study, commandé par le Département paix et sécurité de l'Union africaine, 2010

57 Ndiaye M., The relationship between the AU and the RECs/RMs in relation to peace and security in Africa: subsidiarity and inevitable common destiny, ed. de Coning, Gelot and Karlsrud, p. 52.

58 Gebrehiwot B. M., de Waal A., Peace missions in Africa: constraints, challenges and opportunities, Preliminary Report to the African Union, World Peace Foundation, Mars 2015, p. 19-22. 
States support the role of the AU as the main peace actor, especially because of cross-border crime and international and global developments affecting African states. The Sahel-Saharan States, in the Nouakchott Declaration, 2014: "reiterate the imperative need for the continuation of the capacity building" of the PSC and "encourage the Commission to intensify its efforts to obilize the necessary resources for this purpose".

And in the Declaration on the Tenth Anniversary of the PSC, the Heads of State emphasized the importance of staying close to their promises in setting up APSA and that: "The Council should more effectively and efficiently discharge its mandate", as defined in the Protocol..$^{59}$ The Assembly's analyzed statements regarding the activities of the PSC show how state leaders urge and underline the importance of providing the PSC with sufficient resources and note with gratitude the peace and stability achieved by the $\mathrm{AU} .^{60}$

In accordance with the Constitutive $\mathrm{Act}^{61}$ and the Protocol Relating to the Establishment of the AU Peace and Security Council ${ }^{62}$, the African Union has "the right to intervene in a Member State pursuant to a decision of the Assembly, in respect of grave circumstances, namely: war crimes, genocide and crimes against humanity".

The Protocol on the Amendments to the Constitutive Act expanded the scope of the African Union's intervention in cases of "serious threat to the internal affairs of States". ${ }^{63}$ By adopting such a standard in the AU, the biggest challenge has been to identify a legal mechanism that would allow

59 Protocol Relating to the Establishment of the AU Peace and Security Council. 26.12.2013, art. 4 [online] https://www.peaceau.org/uploads/psc-protocol-en.pdf (accessed 15.10.2019)

60 African Union Assembly, Solemn Declaration of the Assembly of the Union on the Situation in Mali. 2013.20 [online] http://www.peaceau.org/uploads/au.ahg.solemndeclaration.mali.pdf (accessed 15.10.2019).

61 African Union Constitutive Act of the African Union. 11.07.2000, Lome, Togo. Art. 4. (h) [online] https://au.int/sites/default/files/pages/34873-file-constitutiveact_en.pdf (accessed 28.12.2020)

62 Protocol Relating to the Establishment of the AU Peace and Security Council. 26.12.2013, art. 4 [online] https://www.peaceau.org/uploads/psc-protocol-en.pdf (accessed 15.10.2019).

63 African Union Constitutive Act of the African Union. 11.07.2000, Lome, Togo. Art. 4. (h) [online] https://au.int/sites/default/files/pages/34873-file-constitutiveact_en.pdf (accessed 28.12.2020). 
African Architecture to avoid the principle of non-intervention, which is generally presented as an obstacle to peaceful resolutions.

Moreover, this option played a crucial role in violating the prior agreement to a conflict of the parties, which is a sine qua non condition regarding the peaceful resolution of conflicts. The essential thing we can remember from this normative change ${ }^{64}$ of the legal regime within the African Union is that beyond the purpose of resolving conflicts, its vocation is to suppress both systematic violence against the civilian population and to impose respect for democratic principles in cases of unconstitutional change of governments. These are the coercive measures that have been carried out, or that will be used in the context of the conflicts generated by the struggles for political power in the CAR, Mali and South Sudan.

The urgent question is how the AU approaches the sovereignty of the states for which the OAU has been blamed. Direct political interventions are rare, but when they occur, the PSC "reiterates its commitment to the unity, sovereignty and territorial integrity" of the Member State. ${ }^{65}$

If we are to analyze the provisions of the United Nations Charter on this subject, the coercive measures taken by Regional Organizations such as the AU, must be authorized by the United Nations Security Council. The AU has not deviated from this rule, even if, on the one hand, no provision of its statute formally obliges it to comply with this conditionality and, on the other hand, we observe the crystallization of a legal custom in the right to maintain the international peace and security which lies in the fact that Regional Organizations act using coercive measures without the prior authorization of the United Nations Security Council.

64 Derosier J.- Ph., Qu'est-ce qu'une révolution juridique? Le point de vue de la théorie générale du droit. In: Revue française de droit constitutionnel, 2015/2, Nr. 102, pp. 391 404; Kokoroko D., Révolution et droit international. In: Revue Togolaise des Sciences Juridiques, Janvier-Juin 2012 Nr. 0002, p. 7-21.

65 African Union Peace and Security Council, Communiqué. Peace and Security Council 69th meeting, 19 January 2007, Addis Ababa, Ethiopia. 2007. [online] http://www.peaceau.org/uploads/communiqueeng-69th.pdf (accessed 15.10.2019); African Union Peace and Security Council, Communiqué. Peace and Security Council 87th meeting, 13 August 2007, Addis Ababa, Ethiopia. 2008. [online] http://www.peaceau.org/uploads/communiqueeng.pdf (accessed 21.12.2019); African Union Peace and Security Council, Communiqué. Peace and Security Council 826th meeting Addis Ababa, Ethiopia, 9 February 2019. [online] http://www.peaceau.org/uploads/psc.826.meeting.comm.car.9.02.2019.pdf (accessed 15.10.2019) 
This is a remarkable development in this respect, as, in principle, an international organization does not intervene in cases where the question submitted for analysis falls within the national competence of the Member States. However, pursuant to Article 4 (h) of its Constitutive Act that it may intervene in a Member State in certain serious circumstances, the African Union is implementing a real innovation. The question is whether these military interventions, caused by the urgent need to undermine or stop serious violations of state peace and security, can be carried out without the authorization of the United Nations Security Council.

James Mouangue Kobila states that: "in this regard, we could propose the idea of an amendment through the legal custom of Articles 52 and 53 of the UN Charter. Thus, it would no longer be a question of vertical relationships between the UN and Regional Organizations, but of a multifaceted cooperation, giving alternative priority, depending on the operational efficiency of the means implemented to achieve the assigned objective". ${ }^{66}$

However, the lack of financial means resulting from Member States' non-compliance with their financial obligations to the continental organization has been regularly mentioned to justify this faithful position of the AU regarding the principle of the conventional primacy of the Security Council on regional legal orders.

It is easy to understand why, in the CAR and Mali, the AU resorted to the use of force in the context of peace support operations ${ }^{67}$ without the consent of states after the signed peace agreements were intentionally violated. With regard to the CAR, the mediation efforts of the AU and ECCAS following the Putsch did not prevent the situation from escalating, to the point where the PSC had no choice but to find "serious human rights violations". ${ }^{68}$ At the same time, the deployment of the International Support

66 Kobila M., L’Afrique et les juridictions pénales internationales. Centre Thucydide Analyse et recherche en relations internationales Université Panthéon-Assas (Paris II), 2012. p. 49- 51. (51 p.).

67 Les opérations de soutien de la paix sont des opérations multifonctionnelles impliquant des forces militaires et des organisations civiles, notamment humanitaires. Elles ont des objectifs humanitaires ou visent une solution politique à long terme. Voir lexique de droit international humanitaire en ligne disponible sur https://lexdih.wordpress.com/o/operations-de-soutien-de-la-paix/ (accessed 13.02.2017).

68 African Union Peace and Security Council, Communiqué. 13.12.2013, p.4 [online ]https://reliefweb.int/sites/reliefweb.int/files/resources/Communiqu\%C3\%A9\%20de\%20la 
Mission to the Central African Republic (MISCA) consisting of the contingents of ECCAS (MICOPAX) and other African troops, whose mandate was intended to help: “(i) restore security and public order, by implementing appropriate measures,

ii) stabilizing the country and restoring the authority of the Central African state,

iii) reform and restructuring of the defense and security sector ". 69

Therefore, the military intervention in question is strictly aimed at implementing a peaceful solution resorting to coercion. In the same spirit, the AU authorized the deployment (MISCA). We note in these two interventions that the "restoration of the legal order" conditions the restoration of peace undermined by the unconstitutional changes of government that provoke violent conflicts of political struggle. Therefore, the African Peace and Security Architecture is part of the list of instruments for popularizing culture and respecting democratic principles.

However, the imposition of peace by the African Peace and Security Architecture is generally insufficient to fully resolve the conflict. Thus, from a broad perspective, the use of multifunctional operations, involving a civilian structure on the humanitarian and political dimensions in addition to military forces, becomes inevitable. These are operations for the reconstruction of the state after the conflict.

The AU is involved in many actions on the continent and tries to intervene especially by supporting the priority directions of development and community leaders. Its peace policy begins with gathering information and brainstorming with local leaders before the AU opens up the possibility of using various means, including the military. "To this end, the Council emphasized the importance of popularizing the work of the AU, in particular regarding the promotion of peace, security and stability on the continent." ${ }^{\prime \prime 0}$

$\% 20408 \%$ C3\%A8me $\% 20$ r\%C3\%A9union\%20du\%20CPS\%20sur\%20la\%20situation $\% 20$ en\%20Guin\%C3\%A9e-Bissau.pdf (accessed 20.15.2019)

69 African Union Peace and Security Council, Communiqué. 13.12.2013, p. 6 [online ]https://reliefweb.int/sites/reliefweb.int/files/resources/Communiqu\%C3\%A9\%20de\%20la $\% 20408 \%$ C3\% A8me\%20r\%C3\%A9union\%20du\%20CPS\%20sur\%20la\%20situation $\% 20$ en\%20Guin\%C3\%A9e-Bissau.pdf (accessed 20.15.2019)

70 African Union Peace and Security Council, Press Statement. Peace and Security Council, 824th meeting, Addis Ababa, Ethiopia, 5 February 2019. [online] http://www.peaceau.org/uploads/psc.824.press.statement.silencing.the.guns. 5.02.2019.pdf (accessed 23.12.2020). 
The PSC therefore organizes campaigns to celebrate the anniversary of human rights declaration, calls on Member States to implement the Africa Amnesty Month (every November) and to support awareness-raising initiatives, such as African Refugee Day.

The relationship between the AU and the African states is very dynamic. The PSC does not want to violate state sovereignty and a sense of autonomy and intervenes through civil society to ensure "bottom-up" peacebuilding. The AU uses its specific soft power tools to increase its influence on the development of African states and national peace policy, to prevent states from undermining and resisting AU peace efforts.

Other peacebuilding actions carried out by the AU include the protection of demobilization centers overseeing the disarmament, demobilization and reintegration (DDR) process, the integration of former members of insurgent organizations into society, the protection of politicians returned to be part of transitional governments and the security of demobilization centers.

The organization has managed to intervene in cases of unconstitutional seizure of power by military forces, to restore and strengthen democratic regimes and good governance in Africa. Some of the successful cases are: Guinea and Mauritania in 2008, Madagascar in March 2009 and Burkina Faso in 2015.

Member States where a flagrant violation of human rights and constitutional provisions is found may be sanctioned by suspending membership of the organization for a period of up to 6 months. If these actions do not remedy the situation, more coercive measures can be taken and sanctions can be used to ensure compliance with legal rules.

Sanctions such as travel bans and the freezing of the regime's assets were applied to people qualified as instigators of conflict. Sanctions must bring about a positive change in political behavior, lead to the cessation of military action and ensure compliance with legal norms. An example of this is the suspension of the Central African Republic (CAR) between March 2003 and June 2005 due to the coup by military structures. However, when the sanctions were lifted in 2005, the military horde retained its power.

Eritrea was also suspended between April 2009 and January 2011 due to support for insurgents in Somalia. Between December 2010 and April 2011, Ivory Coast was suspended, but the regime refused to hand over power 
after its defeat in the elections. However, the UN-France-AU power forced the current regime to resign and the duly constituted authorities took over. ${ }^{71}$

First, it is clear that there is unequal support from AU members for its peacekeeping operations. The mass of troops for AU peacekeeping missions comes from a very small number of African states. Of the 55 AU members, the main contributing states include Ghana, Rwanda, Senegal, South Africa, Ethiopia, Benin, Nigeria and Egypt.

Thus, South Africa provided the majority of troops deployed for missions in Burundi (2003-2004) and Comoros between 2006 and 2008. In early 2008, Uganda supplied all troops deployed under the AMISOM platform to the Somali peace operation (2007-2012), and South Africa, Rwanda, Nigeria and Senegal were the main contributors of the troops for the AU operation in Sudan (2004-2007). ${ }^{72}$

Although the AU has its own peace fund to finance its operations, in most of the peacekeeping missions carried out, the AU has been financially supported by donors such as the EU, the US, China and various agencies.

For example, the EU has made a financial contribution to military or civilian operations in Africa. For instance, EUR 7 million were allocated to the Artemis mission in the DRC in 2003, EUR 4.3 million to the Kinshasa DRC police mission in 2005-2007, EUR 8.3 million to Somalia Operation in 2008, EUR 5.6 million for the action in Guinea Bissau from 2008 to 2010. Furthermore, the EU allocated around EUR 299 million and provided a large number of troops for peacekeeping actions in Chad between 2008 and 2009 and provided both military training and funding for the mission in Somalia with around EUR 7 million since 2010. ${ }^{73}$

Despite the rhetoric of supporting states, the AU remains dependent on their material contribution. A perpetuating difficulty is the lack of support and political will of states to build APSA and empower PSC. Examples are

71 Williams P. D. The African Union's conflict management capabilities (Working Paper). International Institution and Global Governance Program, New York. 2011. p. 129 [Online] https://www.files.ethz.ch/isn/146220/IIGG_WorkingPaper7.pdf (accessed 21.12.2019)

72 Bergholm L. The African Union, the United Nations and civilian protection challenges in Darfur. Oxford, UK: Refugee Studies Centre, Working Paper Series Nr. 63, 2010. 34 p. [online] https://www.peacepalacelibrary.nl/ebooks/files/338479716.pdf (accessed 15.10.2020)

73 Siradag A. The Eu's security policy towards Africa: Causes, rationales, and dynamics. Insight Turkey, 2012. Nr. 14 (4), p. 177-178. 
the statements on military interventions in Mali (AFISMA) and Somalia (AMISOM). PSC urges "to contribute generously, in a spirit of Pan-African solidarity and shared responsibility, financial, logistical and other support to AFISMA and the MDSF" ${ }^{74}$

The text of the AU Assembly Decision on PSC highlights the reservations and the problematic nature of the role of Member States in supporting military interventions: "PSC...urges AU Member States to provide the military and police personnel necessary to enable AMISOM to reach its authorized capacity, pays tribute to AMISOM and to the countries contributing to the troops, namely: Burundi and Uganda; Calls on the Member States that have pledged to provide troops to ensure that AMISOM fulfills these promises as soon as possible and expresses its gratitude to all Member States and partners who support AMISOM"

PSC acknowledges that the lack of deployed troops is not just a matter of availability. Military capacity and qualified troops require high financial investment from Member States. ${ }^{75} \mathrm{AU}$ calls for the extension of this budget, the change of the defense policy of the Member States and emphasizes the mutual influence between these intervention operations and the states. The essence of the AU is not to be a communication platform or to support only civil society initiatives, but to be a potential military power. The lack of support from the Member States substantially affects the ability to achieve the assigned objectives, being the main peace actor in Africa.

Donors and how to finance peace operations in Africa is a recurring topic. ${ }^{76}$ Most of the costs of peace operations in Africa are borne by external partners, in particular China, the EU (including its Member States), the UN and the United States, which have major implications for African sustainability and capability, as well as for partnerships with these actors. ${ }^{77}$

74 African Union Assembly, Solemn Declaration of the Assembly of the Union on the Situation in Mali. 2013.2 [online] http://www.peaceau.org/uploads/au.ahg.solemndeclaration.mali.pdf (accessed 15.10.2019).

75 African Union Peace and Security Council, Press Statement. Peace and Security Council, 824th meeting, Addis Ababa, Ethiopia, 5 February 2019. [online] http://www.peaceau.org/uploads/psc.824.press.statement.silencing.the.guns. $\quad 5.02$ .2019.pdf (accessed 23.12.2020).

76 Jentzsh C. Opportunities and challenges to financing African Union Peace Operations, African Conflict and Peacebuilding Review, vol. 4, Nr. 2 (Automne 2014), p. 86 -107.

77 Desmidt S., Peacebuilding, conflict prevention and conflict monitoring in the African Peace and Security Architecture, European Centre for Development Policy Management (ECDPM) Background note, Août 2016, p. 7. 
Gebrehiwot and de Waal, for example, argue that the main reason why the AU addresses the UN Security Council is the financial one.

They also point to the gap between Africa's political will to make ambitious political decisions, on the one hand, and the financial resources needed to implement them, on the other. Thus, the AU will not be able to make its own decisions independently with regard to the mandate, framework, size and duration of peace operations, as long as it depends on external partners to finance them. ${ }^{78}$ At the same time, L. Darkwa points out that, although the AU has failed to independently finance its peace operations, the AU Member States have provided troops on the ground essential for new types of peace operations in Africa. ${ }^{79}$

Strategic partnerships and cooperation between the AU and its external partners are a crucial issue. The AU and African states have already established and experienced partnerships with multilateral organizations such as the European Union (EU) and the North Atlantic Treaty Organization (NATO), as well as bilaterally with states such as India, Japan, Russia, China, and Turkey. ${ }^{80}$ There is a broad consensus that a strong strategic partnership remains essential to support and strengthen African peace operations in the near future. ${ }^{81}$ According to De Coning, the continuous development of existing partnerships and the establishment of new partnerships will be important. ${ }^{82}$

78 De Coning C., Adapting the African Standby Force to a just-in-time readiness model: improved alignment with the emerging African model of peace operations. In: De Coning C., Gelot L., Karlsrud J. The Future of African Peace Operations: From the Janjaweed to Boko Haram London: Zed Books, 2016, p. 123-124.

79 Darkwa, L., The strategic relationship between the African Union and its partners. In: De Coning C., Gelot L. Karlsrud J. The Future of African Peace Operations: From the Janjaweed to Boko Haram London: Zed Books, 2016, p. 71.

80 De Coning C., Gelot L. and Karlsrud J., African peace operations: trends and future scenarios, conclusions and recommendations. In: De Coning C., Gelot L. Karlsrud J. The Future of African Peace Operations: From the Janjaweed to Boko Haram London: Zed Books, 2016, p. 136.

81 Boutellis A., Williams P. D., Peace Operations, the African Union, and the United Nations: Toward More Effective Partnerships. International Peace Institute: New York, Apr. 2013, 22 p.; Williams, P.D., Enhancing US support for peace operations in Africa, Council on Foreign Relations, Council Special Report Nr. 73, 2015. 56 p.

82 De Coning C., Gelot L. and Karlsrud J., African peace operations: trends and future scenarios, conclusions and recommendations. In: De Coning C., Gelot L. Karlsrud J. The Future of African Peace Operations: From the Janjaweed to Boko Haram London: Zed Books, 2016, p. 135-136. 
Following the results subjected to analysis, we can see that the Organization of African Unity could not cope with the specific challenges posed by armed conflicts on the African continent, which led to the formation of the African Union. This new structure was to identify the characteristic solutions for overcoming relational crises and ending conflicts in the area.

The most difficult challenge in the peace and security process has proved to be the specific relations between the states of the African continent, which advocated the priority of the principle of sovereign equality in relations with regional and international structures to the detriment of identifying and implementing regional mechanisms and instruments for achieving the assigned objectives.

The African Union in general and the African Peace and Security Architecture, in particular, have been increasingly involved in preventing and combating violations of African peace and security and have proven effective in the field, modeling the approaches, tools and methods of intervention to the specifics and color of the area.

Only in the case of open cooperation, based on mutual trust and the proportionate contribution of all interested persons, including African states, a substantial reduction in the number of armed conflicts or military riots, improving the fate of those affected by these atrocities and preventing the emergence of new conflict situations could ensure the long-awaited state of peace and security in Africa.

Over the two decades of the 21 st century, the African Union has demonstrated its status as an effective regional organization capable of intervening. Despite the financial, communication deficiencies and the divergence of the interests of the states involved, this structure proves to be an inherently necessary one for ensuring peace and security on the African continent. 


\section{Bibliography}

\section{Normative Acts}

African Union Constitutive Act of the African Union. 11.07.2000, Lome, Togo. [online] https://au.int/sites/default/files/pages/34873-file-constitutiveact_en.pdf (accessed 28.12.2020)

African Union High Level Retreat, On the Promotion of Peace, Security and Stability "Strengthening African Union's Conflict Prevention and Peacemaking Effort." 2018. [online] http://www.peaceau.org/uploads/2018-1026-au-hlr-9declarationlatest.pdf (accessed 25.11.2020).

African Union High Level Retreat, Third African Union High-Level Retreat of Special Envoys and Representatives on the Promotion of peace, Security and Stability in Africa. Cairo Declaration. 2012. [online] http://www.peaceau.org/uploads/auc.declaration.cairo.pdf (accessed 23.12.2020).

African Union Assembly, Solemn Declaration of the Assembly of the Union on the $\begin{array}{llll}\text { Situation } & \text { M } & \text { Mali. } & \text { [online] }\end{array}$ http://www.peaceau.org/uploads/au.ahg.solemndeclaration.mali.pdf (accessed 15.10.2019).

African Union Peace and Security Council, Communiqué. Peace and Security Council 826th meeting Addis Ababa, Ethiopia, 9 February 2019. [online] http://www.peaceau.org/uploads/psc.826.meeting.comm.car.9.02.2019.pdf (accessed 15.10.2019).

African Union Peace and Security Council, Press Statement. Peace and Security Council, 824th meeting, Addis Ababa, Ethiopia, 5 February 2019. [online] http://www.peaceau.org/uploads/psc.824.press.statement.silencing.the.guns. 5.02.2019.pdf (accessed 23.12.2020)

African Union Peace and Security Council, Statement of the Chairperson of the Commission of the African Union on the Situation in Zimbabwe. 2017. [online] http://www.peaceau.org/uploads/auc-statement-zimbabwe21nov2017english.pdf (accessed 21.10.2019).

African Union Peace and Security Council, Communiqué. 13.12.2013, [online ]https://reliefweb.int/sites/reliefweb.int/files/resources/Communiqu\%C3\%A9\% 20de $\% 201 \mathrm{a} \% 20408 \% \mathrm{C} 3 \%$ A8me $\% 20$ r\%C3\%A9union\%20du\%20CPS\%20sur $\% 201 \mathrm{a} \% 20$ situation\%20en\%20Guin\%C3\%A9e-Bissau.pdf (accessed 20.15.2019)

African Union Peace and Security Council, Communiqué. Peace and Security Council 87th meeting, 13 August 2007, Addis Ababa, Ethiopia. 2008. [online] http://www.peaceau.org/uploads/communiqueeng.pdf (accessed 21.12.2019). 
African Union Peace and Security Council, Communiqué. Peace and Security Council 69th meeting, 19 January 2007, Addis Ababa, Ethiopia. 2007. [online] http://www.peaceau.org/uploads/ communiqueeng-69th.pdf (accessed 15.10.2019).

Protocol Relating to the Establishment of the AU Peace and Security Council. 26.12.2013 [online] https://www.peaceau.org/uploads/psc-protocol-en.pdf (accessed 15.10.2019)

United Nations Charter. 24.10.1945 [online] https://www.un.org/en/sections/uncharter/un-charter-full-text/ (accessed 23.12.2020)

UN, General Assembly, Report of the High-level Independent Panel on Peace Operations on uniting our strengths for peace: politics, partnership and people (A/70/95-S/2015/446).

\section{Specialized literature}

Agu S. U., Okeke V. O. The African Union (AU) and the challenges of conflict resolution in Africa. British Journal of Arts and Social Sciences, 2013. Nr. 14(11), p. 280-288.

Aning K., Abdallah M. Confronting hybrid threats in Africa: improving multidimensional responses. In: De Coning C., Gelot L., Karlsrud J. The Future of African Peace Operations: From the Janjaweed to Boko Haram London: Zed Books, 2016, p. 20-38.

Badmus I. A., The African Union's Role in Peacekeeping: Building on Lessons Learned from Security Operations, Palgrave Macmillan: Basingstoke, 2015, 277 p.

Barnett M., Coleman L. Designing Police: Interpol and the Study of Change in International Organisations, International Studies Quarterly, 2005, Nr. 49 (4), $\begin{array}{llll}\text { p. } & 598 . & \text { p. } & 593-619 .\end{array}$ line]https://home.gwu.edu/ barnett/articles/2005_designing_isq.pdf (accessed 15.10.2020)

Bergholm, L. The African Union, the United Nations and civilian protection challenges in Darfur. Oxford, UK: Refugee Studies Centre, Working Paper Series Nr. 63, 2010. 34 p. [on line] https://www.peacepalacelibrary.nl/ebooks/files/338479716.pdf [accessed 15.10.2020)

Boutellis A., Williams P. D., Peace Operations, the African Union, and the United Nations: Toward More Effective Partnerships. International Peace Institute: New York, Apr. 2013, 22 p. 
Buzan B., Wever, O. Regions and Powers, the structure of international security. Cambridge: Cambridge University Press, 2003, 570 p.

Darkwa L., The strategic relationship between the African Union and its partners. In: De Coning C., Gelot L., Karlsrud J. The Future of African Peace Operations: From the Janjaweed to Boko Haram London: Zed Books, 2016, p. 65-76.

De Coning C., Adapting the African Standby Force to a just-in-time readiness model: improved alignment with the emerging African model of peace operations. In: De Coning C., Gelot L., Karlsrud J. The Future of African Peace Operations: From the Janjaweed to Boko Haram London: Zed Books, 2016, p. 120-135

De Coning C., Gelot L., Karlsrud J., The Future of African Peace Operations: From the Janjaweed to Boko Haram London: Zed Books, 2016, 155 p.

De Coning C., Gelot L. and Karlsrud J., African peace operations: trends and future scenarios, conclusions and recommendations. In: De Coning C., Gelot L., Karlsrud J. The Future of African Peace Operations: From the Janjaweed to Boko Haram London: Zed Books, 2016, p. 135-145.

Desmidt S., Peacebuilding, conflict prevention and conflict monitoring in the African Peace and Security Architecture, European Centre for Development Policy Management (ECDPM) Background note, Août 2016, 16 p.

Derosier J.- Ph., Qu'est-ce qu'une révolution juridique? Le point de vue de la théorie générale du droit. In: Revue française de droit constitutionnel, 2015/2, Nr. 102, p. 391-404

Dersso S. A., Confronting hybrid threats in Africa: improving multidimensional responses, ed. de Coning, Gelot et Karlsrud. The Future of African Peace Operations: From the Janjaweed to Boko Haram London: Zed Books, 2016, p. 38-52.

Engel U., Porto G. D., Towards an African Peace and Security Regime: Continental Embeddedness, Transnational Linkages, Strategic Relevance. Burlington: Ashgate, 2013. $276 \mathrm{p}$.

Fawcett L. Regional Security. Security Studies an Introduction. London: Routledge, 2013, p. 620.

Freire M. R., Lopes P. D. Nascimento, D., Responsibility to Protect and the African Union: Assessing the AU's Capacity to Respond to Regional Complex Humanitarian and Political Emergencies, African Security Review, 2016, Nr. 25 (3) p. 223-241.

Fisher L. M., African Peace and Security Architecture (APSA): 2010 assessment study, commandé par le Département paix et sécurité de l'Union africaine, 2010. 
Fopy S. Ch., Le droit d'intervention de l'Union Africaine, Mémoire de DEA en Droit Communautaire et comparé CEMAC, Université de Dschang, 2006, 128 p.

Gebrehiwot B. M., de Waal A., Peace missions in Africa: constraints, challenges and opportunities, Preliminary Report to the African Union, World Peace Foundation, Mars 2015, p. 19-22.

Jentzsh C. Opportunities and challenges to financing African Union Peace Operations, African Conflict and Peacebuilding Review, vol. 4, Nr. 2 (Automne 2014), p. 86 -107.

Joshua S. J., Olanrewaju F. The AU's Progress and Achievements in the Realm of Peace and Security. India Quarterly 73(4), Indian Council of World Affairs ICWA, SAGE Publications, 2017. p. 1-17.

Kobila M., L'Afrique et les juridictions pénales internationals. Centre Thucydide Analyse et recherche en relations internationales Université Panthéon-Assas (Paris II), 2012. 51 p.

Kokoroko D., Avons-nous encore besoin du droit international de la démocratie? In: Mélanges François HERVOUET, Entre les ordres juridiques, LGDJ, 2015, p. $752 \mathrm{p}$.

Kokoroko D., Révolution et droit international. In: Revue Togolaise des Sciences Juridiques, Janvier-Juin 2012 Nr. 0002, p. 7-21.

Leijenaar A., Africa can solve its own problems with proper planning and full implementation of the African Standby Force, Blog post, Institute for Security Studies, 21.01.2004, [online] https://www.issafrica.org/iss-today/africa-cansolve-its-ownproblems-with-proper-planning-and-full-implementation-of-theafrican-standby-force>.(accessed 25.09.2019)

Lisk F. The African Union after 10 Years: Successes and challenges. (2012) [online] http://www2.warwick.ac.uk/newsandevents/expertcomment/the_africa n_union/(accessed 05.01.2021)

Lotze W., Strengthening African peace support operations: nine lessons for the future of the African Standby Force, Center for International Peace Operations (ZIF) Policy Briefing, déc. 2013. 4 p.

Makinda S.M., Okumu F. W. The African Union, challenges of globalisation, security and governance. New York: Routledge Global Institutions, 2008, p. 209.

Mehler A. Not always in the people's interest: Power-sharing arrangements in African peace agreements. Hamburg: GIGA Working Papers, 2008. Nr. 83, 44 p.

Murithi T. Proactive interventionism: The African Union, Peace and Security Councils engagement in the Horn of Africa. Journal of Conflict Resolution, Nr. 12, 2012, p. 87-111. 
Murithi T. The African Union's evolving role in peace operations: The African Union Mission in Burundi, the African Union Mission in Sudan and the African Union Mission in Somalia. African Security Review, 17(1), Taylor \& Francis, 2008. p. 70-82.

Ndiaye M., The relationship between the AU and the RECs/RMs in relation to peace and security in Africa: subsidiarity and inevitable common destiny, ed. de Coning, Gelot and Karlsrud, p. 52-65.

Oguonu C. N., Ezeibe, C. C. African Union and conflict resolution in Africa. Mediterranean Journal of Social Sciences, 2014. Nr. 5(27), p. 325-332.

Omorogbe E. Y.. A club of incumbents? The African Union and coups d'etat. Vanderbilt Journal of Transnational Law, 2008. Nr. 44(1), p. 127, p. 123-154. https://www.dphu.org/uploads/ attachements/books/books_3824_0.pdf

Peen R. A., The African Union Mission in Burundi, Civil Wars, 2012, Nr. 14 (3), $376 . \quad$ p. 373-392. [On $\quad$ line] https://centres.exeter.ac.uk/exceps/downloads/Ethnopolitics\%20papers_No10_ peen\%20rodt\%20-\%20african\%20union.pdf (accessed 15.10.2020)

Powell K. The African Union's emerging peace and security regime opportunities and challenges for delivering on the responsibility to protect (ISS Monograph Series No. 119). Pretoria: Institute for Security Studies, 2005. [On line] https://www.africaportal.org/publications/the-african-unions-emerging-peaceand-security-regime-opportunities-and-challenges-for-delivering-on-theresponsibility-to-protect/ (accessed 15.12.2019)

Shinkaiye K. Nigeria and the African Union: Roles and expectation. In B. Akinterinwa (Ed.), Nigeria and the development of the African Union. Ibadan: Vantage Publishers, 2005, p. 76-97

Siradag A. The Eu's security policy towards Africa: Causes, rationales, and dynamics. Insight Turkey, 2012. Nr. 14 (4), p. 175-188.

Soderbaum F., Tavares R. Problematizing regional organisation in African security. African Security. 2009, Nr. 2 (2-3), p. 69-81.

Soderbaum F., Hettne B. Regional security in a global perspective. In: Africa's New Peace and Security Architecture; Promoting Norms, Institutionalizing Solutions. UK: Ashgate. 2010, p. 13-30.

Sturman K., Hayatou A. The Peace and Security Council of the African Union: from design to reality. In: Africa's New Peace and Security Architecture; Promoting Norms, Institutionalizing Solutions. UK: Ashgate, 2010, p. 57-75.

Ulf E., Gomes Porto J. Africa's New Peace and Security Architecture: Promoting Norms, Institutionalizing Solutions. In: Africa's New Peace and Security Architecture; Promoting Norms, Institutionalizing Solutions. UK: Ashgate, 2010, p. 1-12. 
Van der Lijn J., Smit T. et Höghammar T., Peace operations and conflict management, SIPRI Yearbook 2016: Armaments, Disarmament and International Security. Oxford University Press: Oxford, 2016, p. 269-319.

Van der Lijn J., Avezov, X., The Future Peace Operations Landscape: Voices from Stakeholders Around the Globe, Final Report of the New Geopolitics of Peace Operations Initiative, SIPRI: Stockholm, 2015.90 p.

Vines A. A decade of African Peace and Security Architecture. International Affairs. Nr. 89 (1), 2013, p. 89-109.

Williams P. D. War and conflict in Africa. Cambridge: Polity Press, 2011, p. 306 p.

Williams P. D. The African Union's conflict management capabilities (Working Paper). International Institution and Global Governance Program, New York. 2011. 1 p. $1-29 \quad$ [On $\quad$ line] https://www.files.ethz.ch/isn/146220/IIGG_WorkingPaper7.pdf (accessed 21.12.2019)

Williams P. D., Boutellis, A., Partnership peacekeeping: challenges and opportunities in the United Nations- African Union relationship, African Affairs, 2014, vol. 113, no. 451, p. 254 - 278

Williams P.D., The Peace and Security Council of the African Union: Evaluating an Embryonic International Institution', Journal of Modern African Studies 47 (4), 2009, p. 603-626.

Williams P. D., The "Responsibility to Protect", Norm Locatisation, and African International Society, Global Responsibility to Protect, 2009, Nr. 1 (3), p. 392 416.

Williams P.D., Enhancing US support for peace operations in Africa, Council on Foreign Relations, Council Special Report Nr. 73, 2015. 56 p. 
